\title{
Efek Xilooligosakarida (XOS) dalam Mencegah Diabetes Mellitus Tipe 2
}

\section{Effects of Xylo-oligosaccharide (XOS) in Preventing Type 2 Diabetes Mellitus}

\author{
Lusi Putri Dwita*, Hanifah Rahmi \\ Faculty of Pharmacy and Science, Universitas Muhammadiyah Prof. DR HAMKA, Jakarta, Indonesia
}

\begin{abstract}
ABSTRAK
Diabetes mellitus tipe 2 (DMT2) termasuk salah satu penyakit penyebab kematian yang tinggi di Indonesia. Intervensi dini sangat penting untuk menunda perkembangan penyakit ini. Penelitian ini bertujuan untuk mengetahui efek pemberian prebiotik XOS (Xilooligosakarida) dalam mencegah resistensi insulin. Hewan coba dibagi menjadi 5 kelompok yang masing-masing diberikan XOS 2 gr/ $\mathrm{kg}$, XOS $1 \mathrm{gr} / \mathrm{kg}$, XOS $0.5 \mathrm{gr} / \mathrm{kg}$, kontrol diabetes, dan kontrol non- diabetes. Hewan diberikan zat uji dan pakan standar selama 2 minggu, kemudian diinduksi dengan STZ (streptozotosin) kecuali kontrol non-diabetes. Pada hari ke-19 dilakukan pengambilan data gula darah dan kolesterol total. Hasil penelitian menunjukkan pemberian XOS 2 gr $/ \mathrm{kg}$ bb dapat mencegah kenaikan gula darah tertinggi $(57.84 \%)$ dan menunjukkan kadar kolesterol yang sebanding terhadap kontrol normal. Hasil penelitian ini menunjukkan bahwa pemberian XOS dapat memberikan efek signifikan dalam mencegah DMT2.
\end{abstract}

Revised: March 2019

Accepted: July 2019

\section{Kata kunci: XOS; prebiotik; DMT2}

\begin{abstract}
Type 2 diabetes mellitus (T2DM) is one of the leading causes of death in Indonesia. Early intervention is very important to delay the development of this disease. This study aimed to determine the effect of XOS (Xylo-oligosaccharide) as prebiotic in preventing insulin resistance. The rats were divided into 5 groups: XOS $2 \mathrm{gr} / \mathrm{kg}$, XOS $1 \mathrm{gr} / \mathrm{kg}$, XOS $0.5 \mathrm{gr} / \mathrm{kg}$, diabetic control, and non-diabetic control. Animals were given the test substances and standard feed for 2 weeks then induced with STZ (streptozotocin) except for non-diabetic control. On the 19th day, the data was collected. The results showed that XOS $2 \mathrm{gr} / \mathrm{kg}$ BW could prevent blood sugar elevation which is $57.84 \%$ lower than diabetic control and show a comparable cholesterol level to normal control. It can be concluded that administration of XOS showed a significant effect in preventing T2DM.
\end{abstract}

Key words: XOS; prebiotic; T2DM

*Corresponding author

Email : lusi_putridwita@uhamka.ac.id

\section{PENDAHULUAN}

Organisasi Kesehatan Dunia (WHO) (2016) memperkirakan bahwa jumlah penderita diabetes akan meningkat dari 171 juta pada tahun 2000 menjadi 366 juta pada tahun 2030; terutama di negara- negara berkembang. Diabetes Mellitus Tipe 2 (DMT2), yakni diabetes dengan resistensi insulin dan atau gangguan sekresi insulin, menyumbang 90-95\% dari semua kasus diabetes (American Diabetes Association, 2014). Diabetes mellitus tipe 2 termasuk masalah kesehatan yang tinggi di Indonesia (Widyahening et al., 2014). Hasil survey Kementerian Kesehatan Indonesia (RISKESDAS) pada tahun 2007 menemukan bahwa prevalensi diabetes di Indonesia adalah sekitar $6 \%$, jumlah ini setara dengan lebih dari 12 juta penduduk Indonesia.
Kebanyakan pasien DMT2 mengalami obesitas, dan sebaliknya, obesitas juga dapat menyebabkan resistensi insulin. Meskipun beberapa pasien diabetes memiliki berat badan normal, namun terdapat peningkatan lemak tubuh terutama di daerah perut (American Diabetes Association, 2014).

Mikrobiota usus terutama terdiri dari tujuh divisi bakteri, yaitu, Firmicutes, Bacteroides, Proteobacteria, Fusobacteria, Verrucomicrobia, Cyanobacteria dan Actinobacteria. Firmicutes dan Bacteroides adalah spesies yang paling banyak terdapat di usus (Yang et al., 2009). Bakteri usus memainkan peran penting dalam peningkatan imunitas, ekstraksi energi dari makanan, fermentasi serat makanan untuk menghasilkan (Short Chain Fatty Acid) SCFA, perubahan metabolisme asam lemak dan glukosa, pengaturan permeabilitas usus, 
produksi vitamin dan peningkatan penyerapan mineral pada manusia (Kellow et al., 2014).

Prebiotik merupakan komponen makanan yang tidak tercerna, yang dapat merangsang pertumbuhan mikroorganisme untuk tujuan meningkatkan fungsi pencernaan (Elizabeth et al., 2003). Xilooligosakarida (XOS) telah diteliti sebagai prebiotik yang mampu secara signifikan meningkatkan bifidobacterial usus dengan konsumsi relatif rendah (2.8 g per hari) (Slavin, 2013). Hasil penelitian menunjukkan bahwa makanan tinggi lemak dapat meningkatkan lipopolisakarida (LPS) plasma (endotoksemia metabolik), dimana akan berdampak pada peningkatkan berat badan, gula darah puasa dan inflamasi. Ini adalah salah satu mekanisme yang menjelaskan hubungan antara mikrobiota usus, regulasi penyimpanan lemak dan perkembangan obesitas serta DMT2 (Lau et al., 2015). Intervensi prebiotik telah terbukti dapat menunda timbulnya penyakit ini. Suplementasi oligofructose, yang meningkatkan jumlah Bifidobacteria, dapat mengurangi LPS plasma dan sitokin proinflamasi di jaringan adiposa (Cani et al., 2007). Penelitian lain juga menunjukkan bahwa suplementasi prebiotik selama 5 minggu bisa menurunkan kadar HbA1c dan LPS plasma secara signifikan pada pasien DMT2 (Kellow et al., 2014). Hasil penelitian menunjukkan hewan yang diinduksi obesitas dan DMT2 mengalami penurunan Bifidobacteria dan peningkatan bilophila secara signifikan (Everard et al., 2011). Pengembangan prebiotik dari sumber daya alam untuk penunjang kesehatan pasien DMT2 masih belum cukup berkembang di Indonesia. Oleh karena itu, dalam penelitian ini akan dilakukan uji potensi prebiotik XOS untuk mencegah diabetes mellitus tipe 2 .

\section{METODE}

\section{Alat dan Bahan Penelitian}

Streptozotocin (STZ) (P.T Praglas Jaya), Xilooligosakarida (XOS) (Henan Heagreen, Zhoukou, China), dan ketamin. Alat- alat yang digunakan pada penelitian ini antara lain adalah kandang hewan uji yang dilengkapi tempat pakan dan minum, timbangan hewan, timbangan analitik, sonde oral, labu ukur, mikropipet Eppendorf, mikrotube, tip, vortex.

\section{Hewan Uji}

Hewan yang digunakan dalam percobaan yaitu tikus putih (Ratus norvegicus) strain Sprague Dawley. Tikus yang digunakan berumur 2-3 bulan sebanyak 25 ekor yang dibagi menjadi 5 kelompok yang masing-masing kelompok terdiri dari 5 ekor dengan berat badan tikus 200 - 250 g. Sebelum perlakuan tikus diaklimatisasi terlebih dahulu pada kandang suhu $23 \pm 1{ }^{\circ} \mathrm{C}$ dengan siklus gelap/ terang 12 jam selama 7 hari agar hewan percobaan dapat beradapatasi dengan lingkungan yang baru dan untuk mencukupkan bobot hewan percobaan dengan diberi minum dan pakan standar secukupnya.

\section{Perlakuan terhadap Hewan Uji}

Tikus sebanyak 25 ekor dibagi menjadi 5 kelompok, kelompok 1 (kontrol non-diabetes), kelompok 2 (XOS $2 \mathrm{~g} / \mathrm{kg}$ ), kelompok 3 (XOS $1 \mathrm{~g} / \mathrm{kg}$ ), kelompok 4 (XOS $0.5 \mathrm{~g} / \mathrm{kg}$ ), kelompok 5 (kontrol diabetes). Kelompok 2,3,4 diberikan pakan standar dan XOS (terlarut dalam aquades) p.o selama 2 minggu, sedangkan kelompok 1 dan 5 hanya diberi pakan standar. Hari ke 14, tikus diinduksi menggunakan STZ dalam dapar sitrat 0.1 M $(\mathrm{pH}=4)(40 \mathrm{mg} / \mathrm{kg}$, i.p) (Gauthier, 2014). Lima hari setelah injeksi STZ, dilakukan pengukuran kadar gula darah dan kolesterol total (Majd, et al. 2018).

\section{Metode Pengambilan Darah dan Serum Darah}

Sebelum dilakukan pengambilan darah, tikus dipuasakan selama \pm 16 jam. Tikus dianastesi dengan ketamin i.p 60 $\mathrm{mg} / \mathrm{kg} \mathrm{BB}$, hingga tak sadarkan diri,kemudian dilakukan pengambilan darah melalui sinur orbital. Darah di ambil $2 \mathrm{ml}$ dalam microtube dan di sentrifugasi pada $4000 \mathrm{rpm}$ selama 15 menit untuk memperoleh serum (Vogel, 2008).

\section{Pengukuran Kadar Glukosa Darah}

Serum darah diambil dengan menggunakan mikro pipet sebanyak $10 \mu \mathrm{l}$ dan ditambahkan $1000 \mu \mathrm{l}$ reagen kit glukosa. Kemudiaan divorteks \pm 1 menit hingga homogen dan inkubasi selama 5 menit pada suhu $37^{\circ}$ C. Pengukuran kadar glukosa darah dilakukan menggunakan spektrofotometer klinikal.

\section{Pengukuran kadar kolesterol total}

Serum darah diambil dengan menggunakan mikro pipet sebanyak $10 \mu \mathrm{l}$ dan ditambahkan $1000 \mu \mathrm{l}$ reagen kit kolesterol. Kemudiaan divorteks \pm 1 menit dan inkubasi selama 15 menit pada suhu $37^{\circ} \mathrm{C}$. Pengukuran kadar kolesterol total dilakukan menggunakan spektrofotometer klinikal.

\section{Analisa Data}

Analisis data dilakukan menggunakan metode One-way ANOVA dilanjutkan dengan uji Tukey.

\section{HASIL DAN PEMBAHASAN}

Penyebab diabetes mellitus tipe 2 (DMT2) pada dasarnya karena ketidakseimbangan nutrisi yang dikonsumsi oleh seseorang, kelebihan kalori dan lemak dalam jangka panjang dan kurangnya serat. Ketidakseimbangan diet ini bisa mengakibatkan disbiosis, yang ditandai dengan perubahan dalam komposisi mikrobiota, perubahan aktivitas metabolisme bakteri dan/atau perubahan distribusi mikrobiota usus (Delzenne et al., 2013). Salah satu cara mencegah DMT2 adalah dengan pendekatan gizi. Suplementasi prebiotik yang bermanfaat 
Tabel 1. Kadar glukosa darah

\begin{tabular}{lll}
\hline Kelompok & $\begin{array}{l}\text { Kadar Glukosa Darah } \\
(\mathbf{m g} / \mathbf{d L})\end{array}$ & Penurunan (\%) \\
\hline XOS 2 gr/kg & $179.75 \pm 15.62^{\mathrm{ab}}$ & 57.84 \\
XOS 1 gr/kg & $247.86 \pm 12.45^{\mathrm{ab}}$ & 41.86 \\
XOS 0.5 gr/kg & $366.86 \pm 5.38^{\mathrm{ab}}$ & 13.95 \\
Kontrol non-diabetes & $132 \pm 7.16^{\mathrm{a}}$ & - \\
Kontrol diabetes & $426.33 \pm 7.04^{\mathrm{b}}$ & - \\
\hline aberbeda bermakna dengan kontrol diabetes $(\mathrm{P}<0,05)$, & \\
b berbeda bermakna terhadap kontrol non-diabetes $(\mathrm{P}<0,05)$
\end{tabular}

Table 2. Berat badan hewan uji selama pemberian prebiotik

\begin{tabular}{llllllll}
\hline \multirow{2}{*}{ Kelompok } & \multicolumn{7}{c}{ Berat badan tikus (gr) Hari ke- } \\
\cline { 2 - 8 } & 2 & 4 & 6 & 8 & 10 & 12 & 14 \\
\hline XOS 2 gr/kg & 183.25 & 189.63 & 193.5 & $186.38^{*}$ & 195.75 & $199.13^{*}$ & $199.63^{*}$ \\
XOS 1 gr/kg & 197.63 & 203.75 & 210.5 & 207.13 & 210.38 & 213.38 & 214.38 \\
XOS 0.5 gr/kg & 182.75 & 190.13 & 193 & 197 & 196.75 & 201 & 201.75 \\
Kontrol non-diabetes & 208.2 & 214.6 & 221.4 & 224.2 & 229.4 & 232 & 237.2 \\
Kontrol diabetes & 203.2 & 221.8 & 235 & 240 & 244.4 & 251.2 & 250.6 \\
\hline
\end{tabular}

"berbeda bermakna dengan kontrol diabetes $(\mathrm{P}<0,05)$

merangsang pertumbuhan mikrobiota usus diketahui memiliki efek yang menguntungkan bagi kesehatan dan berdampak positif pada kondisi DMT2.

Penelitian menunjukkan pada pasien DMT2 terjadi peningkatan bakteri patogen oportunistik, seperti Bacteroides caccae, Clostridium hathewayi, Clostridium ramosum, Clostridium symbiosum, Eggerthella lenta dan Escherichia coli, serta terjadi penurunan beberapa jenis bakteri penghasil butirat (Lactobacillus dan bifidobacter) (Lau et al., 2015). Salah satu upaya peningkatan proliferasi mikroorganisme produsen butirat adalah melalui pemberian prebiotik, yang telah banyak diketahui memiliki efek positif terhadap kesehatan dan berdampak baik pada fungsi gastrointestinal (Kellow et al., 2014; Devaraj et al., 2013).

Pada penelitian ini lakukan pemberian prebiotik XOS (Xilooligosakarida) pada hewan uji selama dua minggu sebelum dilakukan induksi diabetes menggunakan STZ (Streptozotocin). STZ telah diketahui dapat menyebabkan DMT2 cara memasuki sel $\beta$ pankreas melalui transporter glukosa (GLUT2). STZ menyebabkan alkilasi DNA, pembentukan radikal superoksida dan penghambatan superoksida dismutase (Gauthier, 2014). Hasil pada Tabel 1 menunjukkan pemberian XOS dapat mencegah peningkatan gula darah pada hewan yang diinduksi STZ. Kelompok yang diberikan XOS 2 gr/kg bb dapat mencegah kenaikan gula darah tertinggi yaitu $57.84 \%$ lebih rendah dibandingkan kontrol diabetes, diikuti oleh kelompok XOS $1 \mathrm{gr} / \mathrm{kg}$ dan $0.5 \mathrm{gr} / \mathrm{kg}$. Meskipun demikian pemberian XOS selama dua minggu belum dapat mencegah kerusakan beta pangkreas secara keseluruhan. Hal ini ditunjukkan dengan kadar gula darah kelompok XOS yang belum sebanding terhadap kontrol normal.

Selama dua minggu pemberian prebiotik XOS, dilakukan pengukuran berat badan hewan seperti pada Tabel 2 . Dosis tertinggi XOS menunjukkan efek terhadap berat badan hewan uji. Meskipun juga mengalami peningkatan seperti kelompok lain, namun pemberian XOS dosis 2 gr/ $\mathrm{kg}$ menunjukkan peningkatan berat badan paling rendah dan berbeda signifikan dibandingkan kontrol.

Pada penelitian ini dilakukan juga pengukuran kadar kolesterol darah hewan uji (Tabel 3). Kadar kolesterol hewan uji yang diberikan XOS menunjukkan perbedaan signifikan $(\mathrm{p}<0.05)$ dibandingkan kontrol diabetes. Hal ini menunjukkan pemberian XOS dapat mencegah peningkatan kadar kolesterol hewan. Namun demikian kadar kolesterol hewan uji masih sedikit lebih besar dibandingkan kontrol normal. Dari ketiga kelompok dosis XOS, pemberian XOS 2 gr/kg menunjukkan kadar kolesterol yang sebanding terhadap kontrol normal. Sehingga dapat disimpulkan pemberian XOS pada dosis ini dapat mencegah peningkatan kadar kolesterol pada kondisi resisten insulin. Penelitian yang telah ada menunjukkan pemberian XOS $4 \mathrm{~g} /$ hari dapat menurunkan glukosa darah, LDL, dan total kolesterol pada pasien DMT2 [12]. Penelitian ini membuktikan pemberian XOS dengan dosis lebih kecil dapat mencegah DMT2. 
Tabel 3. Kadar kolesterol total darah

\begin{tabular}{lll}
\hline Kelompok & $\begin{array}{l}\text { Kadar kolesterol total darah } \\
\text { (mg/dL) }\end{array}$ & Penurunan (\%) \\
\hline XOS 2 gr/kg & $193.75 \pm 6.13^{\mathrm{a}}$ & 45.73 \\
XOS 1 gr/kg & $243.43 \pm 18.53^{\mathrm{ab}}$ & 31.81 \\
XOS 0.5 gr/kg & $306.85 \pm 20.44^{\mathrm{ab}}$ & 14.05 \\
Kontrol non-diabetes & $181.2 \pm 13.32^{\mathrm{a}}$ & - \\
Kontrol diabetes & $357 \pm 15.3^{\mathrm{b}}$ & - \\
\hline
\end{tabular}

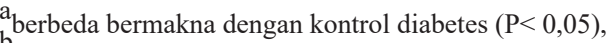

$\mathrm{b}_{\text {berbeda bermakna terhadap kontrol non-diabetes }(\mathrm{P}<0,05)}$

\section{KESIMPULAN}

Pemberian xilooligosakarida selama dua minggu pada tikus secara signifikan dapat mencegah diabetes mellitus tipe 2 akibat induksi streptozotosin.

\section{UCAPAN TERIMA KASIH}

Terima kasih kami sampaikan kepada Lembaga Penelitian dan Pengembangan (Lemlitbang) Universitas Muhammadiyah Prof. DR. HAMKA, Jakarta, yang telah membiayai penelitian ini.

\section{DAFTAR ACUAN}

American Diabetes Association. (2014). Diagnosis and classification of diabetes mellitus. Diabetes Care, 37(January), 81-90. https://doi.org/10.2337/dc14-S081

Cani, P. D., Neyrinck, A. M., Fava, F., Knauf, C., Burcelin, R. G., Tuohy, K. M., Delzenne, N. M. (2007). Selective increases of bifidobacteria in gut microflora improve high-fat-diet-induced diabetes in mice through a mechanism associated with endotoxaemia. Diabetologia, 50(11), 2374-2383. https://doi.org/10.1007/s00125-0070791-0

Delzenne, N. M., Neyrinck, A. M., \& Cani, P. D. (2013). Gut microbiota and metabolic disorders : how prebiotic can work? British Journal of Nutrition. https://doi.org/10.1017/S0007114512004047

Devaraj, S., Hemarajata, P., \& Versalovic, J. (2013). The human gut microbiome and body metabolism: Implications for obesity and diabetes. Clinical Chemistry, 59(4), 617-628. https://doi.org/10.1373/ clinchem.2012.187617

Elizabeth, A., Loo, J. Van, \& George, C. (2003). Nutritional responses to the presence of inulin and oligofructose in the Diets of Domesticated Animal: A Review. Critical Reviews in Food Science and Nutrition, 43(1), 19-60.
Everard, A., Lazarevic, V., Derrien, M., Girard, M., Muccioli, G. G., Neyrinck, A. M., ... Cani, P. D. (2011). Responses of Gut Microbiota and Glucose and Lipid Metabolism to Prebiotics in Genetic Obese and DietInduced Leptin-Resistant Mice, 60(November), 27752786. https://doi.org/10.2337/db11-0227

Gauthier, E. L. (2014). Streptozotocin Uses, Mechanism of Action, and Side Effects. (E. L. Gauthier, Ed.). New York: Nova Science Publishers, Inc.

Kellow, N. J., Coughlan, M. T., \& Reid, C. M. (2014). Systematic Review Metabolic benefits of dietary prebiotics in human subjects : a systematic review of randomised controlled trials, 1147- 1161. https://doi. org/10.1017/S0007114513003607

Lau, E., Carvalho, D., Pina-vaz, C., Barbosa, J., \& Freitas, P. (2015). Beyond gut microbiota : understanding obesity and type 2 diabetes, 14(3), 358-369.

Majd, N. E., Tabandeh, M. R., Shahriari, A., \& Soleimani, Z. (2018). Okra (Abelmoscus esculentus) Improved Islets Structure, and Down-Regulated PPARs Gene Expression in Pancreas of High- Fat Diet and Streptozotocin-Induced Diabetic Rats. Cell Journal, 20(1), 31-40. https://doi.org/10.22074/cellj.2018.4819

Slavin, J. (2013). Fiber and Prebiotics: Mechanisms and Health Benefits, 1417-1435. https://doi.org/10.3390/ nu5041417

Widyahening, I. S., Graaf, Y. Van Der, Soewondo, P., \& Glasziou, P. (2014). Awareness, agreement, adoption and adherence to type 2 diabetes mellitus guidelines: a survey of Indonesian primary care physicians, 1-8.

Yang, X., Xie, L., Li, Y., \& Wei, C. (2009). More than $9,000,000$ unique genes in human gut bacterial community: Estimating gene numbers inside a human body. PLOS ONE, 4(6). https://doi.org/10.1371/journal. pone. 0006074 